\title{
A székesfehérvári Szüz Mária prépostság egykori boltozatai
}

\author{
SZŐKE BALÁZS \\ Pazirik Kft., SZIME 3D AR, Református Líceum Gödöllő \\ H-2100 Gödöllő, Ifjúság u. 22., szokebalazs74kice@gmail.com
}

\begin{abstract}
Szőke, B.: The vaults of the Provostry and Church of the Virgin Mary at Székesfehérvár
Abstract: The Provostry and Church of the Virgin Mary (Szűz Mária) at Székesfehérvár went through several reconstructions in the Middle Ages. The last significant expansion was initiated by Matthias Corvinus. The late Gothic elements of the Provostry's vault was found by Imre Henszlmann in the territory of the ruined monument in the 1860's. The rib vault dating back to the period of Matthias Corvinus was annexed to the buttress built in the Angevin Era. The construction with internal buttresses could come into existence as a consequence of this fixity in the building technique. Examples for this can be found in the Franciscan Church in Szeged-Alsóváros, and in several churches in Transylvania.
\end{abstract}

Keywords: net vault, rib vault, late gothic, 3D digitizing, Székesfehérvár, internal buttress, Matthias Corvinus, Imre Henszlmann

\section{A bazilika építéstörténete}

Székesfehérváron állt 1601. évi pusztulásáig Magyarország koronázó temploma, amelyben középkori királyaink többségét a trónra emelték. A prépostságot maga Szent István király alapította, és sírja is ebben az épületben volt. Ide temették többek között Szent Imre herceget, Könyves Kálmánt, III. Bélát, Anjou Károly Róbertet, Anjou Nagy Lajost, Hunyadi Mátyást, Jagelló II. Ulászlót és II. Lajost is. Az újonnan trónra került dinasztiák számára különösen fontos volt, hogy legitimációjukat az Árpád-házzal való kapcsolattal is hangsúlyozzák, így az Árpád-kori szokástól eltérően, mikor a sok uralkodó új alapítású egyházban jelölte ki nyughelyét ${ }^{1}$ ők a székesfehérvári bazilikát választották temetkezési helyüknek. Az Anjouk Székesfehérvár átépítésével, fényének emelésével kívánták uralmuk emlékét maradandóvá tenni.2 Szent István király bazilikájának első átépítése még az Árpád-korban a 11-12. században történt, megadva a későbbi építkezések keretét. ${ }^{3}$ Ezt a román stílusú templomot Károly Róbert és Nagy Lajos idején gótikus stílusban átépítették, megköpenyezve az eredeti szerkezeteket. A falakat így boltozatok hordására is alkalmassá tették. A források szerint az addig famennyezetes épület többször leégett, így mennyezetét és tetőszerkezetét is újjá kellett építeni. ${ }^{4}$ Először a főhajóra készült új famennyezet, később elkészültek a templom beboltozásának tervei: a mellékhajókat le is fedték bordás gótikus keresztboltozatokkal, a főhajót pedig hatsüveges keresztboltozatokkal akarták beboltozni. Az első kísérlet után, amelyet talán még építése közben elvetettek, a főhajó 17 méteres szélességű terébe erősen beálló belső támpilléreket építettek, amelyek több mint 14 méter fesztávolságú ugyancsak hatsüveges keresztboltozatokat tartottak volna. ${ }^{5}$ Közvetett adatok alapján úgy véljük ez a boltozatás sem készült el, ${ }^{6}$ a belsőt a 15. század utolsó negyedéig a Károly Róbert által készíttetett famennyezet fedte le. Nagy Lajos király egy pompás oldalkápolnával bővítette a bazilikát, amelyben saját síremlékét is felállítatta. Luxemburgi Zsigmond idején épült a templom gótikus stílusú délnyugati tornya, de az uralkodó nem ide, hanem felesége, Anjou Mária királynő mellé, Szent László királynak a nagyváradi katedrálisban álló sírjához kívánt temetkezni, így a nagyváradi építkezéseket helyezte előtérbe. A legitimációs problémákkal küzdő Hunyadi Mátyás újra Székesfehérvár felé fordul, és minden eddiginél nagyobb szabású átépítésbe kezdett a prépostság templomán. ${ }^{7}$ Elkezdte egy új, késő gótikus, körüljárós csarnokszentély építését, amely keleti irányban majdnem kétszeresére növelte volna az épületet. Ez az építkezés azonban Mátyás haláláig biztosan nem készült el, és későbbi befejezése sem látszik valószínűnek. A források szerint azonban elkészült a régi főhajó új boltozata, amely az Anjou-kori falpillérekre támaszkodott. ${ }^{8}$ Ez a szerkezet egy a kor legmagasabb színvonalán álló hálóboltozat lehetett. A székesfehérvári kőtárban fellelhető kőtöredékek alapján ennek a boltozatnak a rajzi rekonstrukciójára teszünk kísérletet.

1 Például Tihanyban I. András, Szekszárdon I. Béla temetkezett.

2 Biczó 2004. 32-35., Buzás 2004. 29-31.

3 Szabó 2010.

4 Szabó 2010., Mentényi 2006. 60.

5 Ennek egyes elemei, boltváll indítás alatti függőleges profilozott tagozatai megvannak a kőtári anyagban.

6 Nagyon nagy számban ismerünk különböző boltozati elemeket, amelyek között azonban nincs ilyen bordatípus.

7 Papp 2005. 18-28.

8 Antonio Bonfini és Ludovicus Tubero leírásai. Már Henszlmann Imre is idézi: Henszlmann 1864. 


\section{A boltozat kőelemeinek eredete}

A kőtári anyagban egy nagyméretű, bordacsomópontjai alapján hálóboltozatként rekonstruálható szerkezet darabjait lehet elkülöníteni a bordaprofil alapján. A bordaprofil az érett gótika formanyelvének megfelelöen körtetagos orrú, amelyet jellegzetesen késő gótikus megoldású pálcák kísérnek a bordatőnél. A tagozatok a késő gótikus szerkesztésmódnak megfelelően áthatásban vannak a bordák kereszteződésénél, sőt a bordaorrok túlfutását is megfigyelhetjük rajtuk, amelyek a késő gótikus építészetben is csak bizonyos múhelyek formanyelvében fordulnak elő. ${ }^{9}$ Ezt a megfigyelést már Henszlmann Imre is megtette és közölte 1864-ben megjelent írásában. ${ }^{10}$ Ebben az akkor előkerült két csomópont közül az egyiket Anjou-kori hatsüveges keresztboltozat zárókövének, a másikat Mátyás-kori keresztboltozat zárókövének írta le ${ }^{11}$, amely megállapítások későbbi munkák elgondolásaira is hatással voltak. Valójában mindkét boltozati bordacsomópont egy-egy késő gótikus boltozathoz tartozott. A nagyobb méretű négyes bordakereszteződés - melyet Henszlmann is Mátyás-korinak mondott - tartozhatott a főhajóboltozathoz, a másik egy nagyon jellegzetes, méretben jóval kisebb boltozathoz, amely formailag a pannonhalmi bencés apátság kerengőjében álló boltozattal megegyező kialakítású volt. Fontos információkat ad számunkra e bordacsomópontok lelőhelye, hiszen a későbbi ásatások ebből a szempontból nem dokumentáltak. ${ }^{12} \mathrm{~A}$ kisebb boltozat csomópontját a déli mellékhajótól keletre az egykori délkeleti torony területén találták meg, itt ekkor a Mátyás-kori csarnokszentély első, támpillérek közti kápolnája állhatott. ${ }^{13}$ A számunkra érdekes nagyobb méretű csomópontot pedig a főhajó délkeleti részén a belső támpillérek környékén lelték. A korábbi, III. Béla király sírját feltáró ásatások során dokumentálták, hogy a főhajó délkeleti részét és a déli mellékhajó keleti részét vastag, bolygatatlan omladékréteg borította az újkori járószint alatt, amely réteg elsősorban bordatöredékeket és téglát tartalmazott. ${ }^{14} \mathrm{Az}$ ehhez a részhez kapcsolódó, nagyrészt az egykori főhajó területére eső részen folytatott Henszlmann Imre 1874-ben ásatásokat, amelynek pontosabb dokumentációját azonban nem ismerjük. ${ }^{15}$ Innen kerülhetett elő a többi, főhajóboltozathoz köthető kőelem.

\section{A boltozati kőelemek leírása}

Meglepően nagy számban maradtak meg a boltozat kőelemei, amelyek négy típusba sorolhatóak. A vízszintezéshez meghagyott illesztő fülek, valamint a bordatövek függőleges síkban állott egykori találkozásai alapján meghatározható, hogy a csomópontok nagy része záradék közeli, négy borda találkozásból összeálló csomópont. Ebből a típusból hét, többségében viszonylag épp kőelemmel rendelkezünk. ${ }^{16}$

A boltozati bordacsomópont emelkedési szöge 10-12\% között mérhető, záradék közeli helyzetben volt a boltozatba beépítve. Alaprajzi vetületben „szarkaláb” alakú, térben két „emelkedő" és két „érkező" bordát köt össze. A bordametsződés a bordák térbeli helyzetét tekintve aszimmetrikus. Az „emelkedő" bordák szöge 120', az „érkező" bordák szöge 60'. A bordaorrok rövid szakaszon túlfutnak egymáson, de a teljes bordaprofil nem jelenik meg a túlfutáson. Az emelkedő bordák áthatása arra utal, hogy az egyik emelkedő helyzetű borda azonos magassági helyzetű csomópontokat összekötő egyenes boltövhöz tartozott.

Három darab keresztező, $X$ alakú köztes helyzetű csomópont is maradt, amelyek a boltozat gerincétől távolabb a szerkesztési íven lejjebb helyezkedtek el. A Henszlmann által talált egyik csomópont ezek közé tartozhat. ${ }^{17}$

A boltozati bordacsomópont emelkedési szöge 24-26\% között mérhető, köztes helyzetben volt a boltozatba beépítve. Alaprajzi vetületben X alakú, térben két „emelkedő" és két „érkezö" bordát köt össze. Az „emelkedö" bordák szöge $60^{\prime}$, az,érkezö" bordák szöge 60'.

A harmadik típusból csak egy, de jó állapotú csomóponti elem maradt meg, ez egy boltváll közeli helyzetű, szimmetrikus, , szarkaláb" alakú csomópont.

Alaprajzi vetületben „szarkaláb" alakú, térben három „emelkedő" és egy „érkező" bordát köt össze. A boltozati bordacsomópont emelkedési szöge 34-36\% között mérhető, alsó boltváll közeli helyzetben volt a boltozatba beépítve. Az „emelkedő" bordák szöge $60^{\prime}$ az „érkező" borda ezekkel 120'-os szöget zár be. Középen két borda folytonos, a másik kettő olyan helyzetű, hogy lehetséges lenne profiltúlfutás, de ezen a csomóponton valószínúleg a meredek metsződések miatt ilyen nem készült.

9 A tagozatok enyhe túlfutása Burkhard Engelberg augsburgi építkezésein jelenik meg, majd a 16. század elején lesz viszonylag gyakran alkalmazott motívum.

10 Henszlmann 1864.

11 Henszlmann 1864. 157., 166.

12 Mentényi 2006. 59-63., 63-68., Henszlmann 1876.

13 A keleti toronypárt a Mátyás-kori építkezések során elbontották, az északi torony és az északi mellékhajó helyére egy nagyméretű, Kálmáncsehi Domonkos prépost kápolnájaként azonosított tér épült, délen pedig támpillérek közötti kápolnák és egy csigalépcsőtorony.

14 Biczó 1999. 16-24., Érdy 1853.

15 Mentényi 2006. 59-63., Henszlmann 1876.

16 A 7 darab köelem $4 / 3$ arányban tükörszimmetrikus párja egymásnak.

17 Henszlmann 1854. 166. 

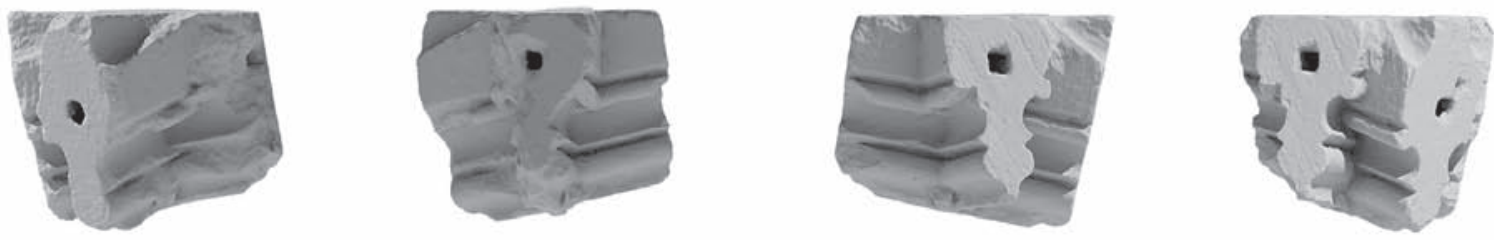

1. kép: Az 1. típusú boltozati bordacsomópont térszkennelt modelljének ortogonális nézetei

A negyedik csomópont egy fecskefarkas boltváll két bordából álló kereszteződése. Ez a csomópont utal arra, hogy a boltozat alaprajzi vetületei rendszerének a többi csomópont alapján rekonstruálható részlete milyen megoldású lehetett. A két lehetséges változat közül ugyanis csak az egyik ad lehetőséget a fecskefarkas keresztezés kialakítására. ${ }^{18}$
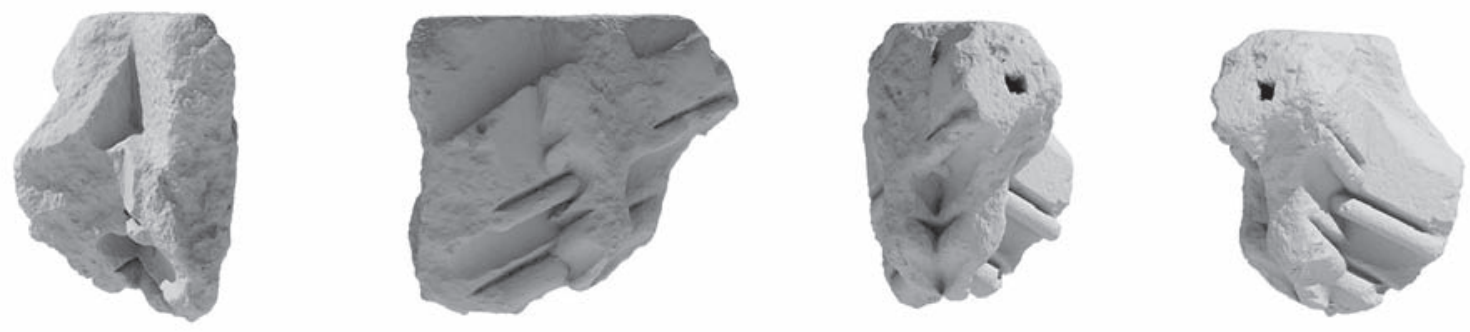

2. kép: A 2. típusú boltozati bordacsomópont térszkennelt modelljének ortogonális nézetei

A boltozatból számos egyenes bordaelem is megmaradt. Ezek bordatöve különböző magasságú és kialakítású. Néhány darabon a boltsüveg bekötésére lefaragott horony látható, ezek feltehetőleg a záradék közeli részen voltak, függőleges bordatövük a profil felett megegyezik a csomópontokéval. Más bordák bordatöve lényegesen magasabb, ezek a boltvállakhoz közelebbi részen lehettek. Ezeken a részeken jelentős függőleges felfalazások után kezdték a valódi süvegfelületek indítását.

A boltozat vállrészéből három kőfaragvány maradt fenn. Ezek közül kettő, egy sarokboltváll indítás, egy legalsó és egy két rétegsorral fentebbi eleme. A boltvállindítás a sarokból indult, és fecskefarkas áthatású volt. Az egyik borda kevéssel lentebb érte el a függőleges síkot, mint a másik, ez a jellegzetesség mindkét kövön jól mérhető.
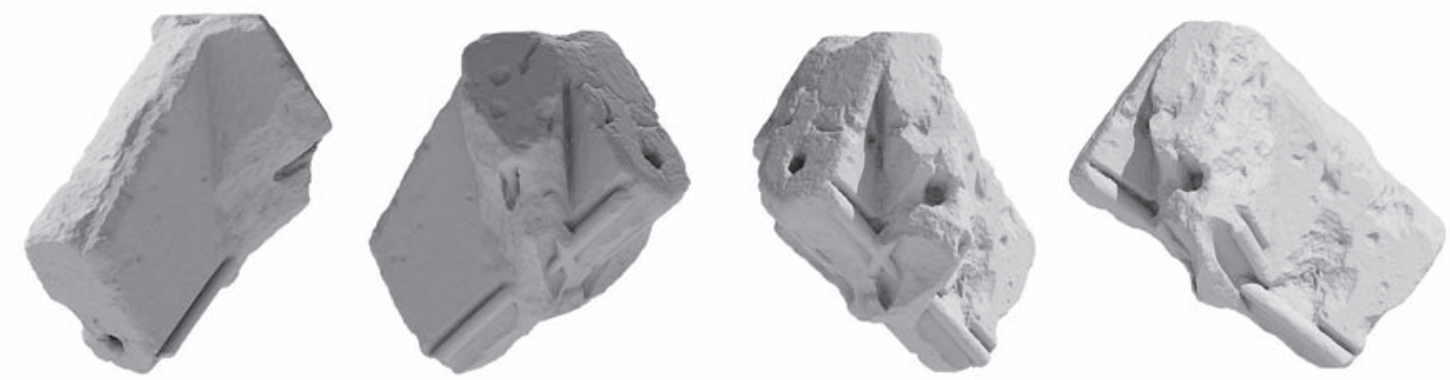

3. kép: A 3. típusú boltozati bordacsomópont térszkennelt modelljének ortogonális nézetei

A másik boltvállhoz tartozó kő egy nagyon nagyméretű köztes boltváll eleme. A belső támpillér boltozathoz kapcsolódó rétegköveinek egyike. A kő másodlagos beépítésből került elő, és a mai napig is szabad téren tárolják. Bizonyos részei erősen kopottak így értelmezésére csak részben tudtunk kísérletet tenni. Bizonyosan látható rajta, hogy a körtetagos profillal képzett, több tagozatból álló függőleges tagolással metsződik össze a boltozat bordarendszere. A függőleges tagolás profilja nem azonos a bordaprofillal. A megmaradt bordaindí-

18 Szőke Balázs: A dési református templom. megjelenés alatt. Az előadás elhangzott a Múemlékvédelem Erdélyben IV. elnevezésű konferencián Szovátán 2010. március 26-án. 

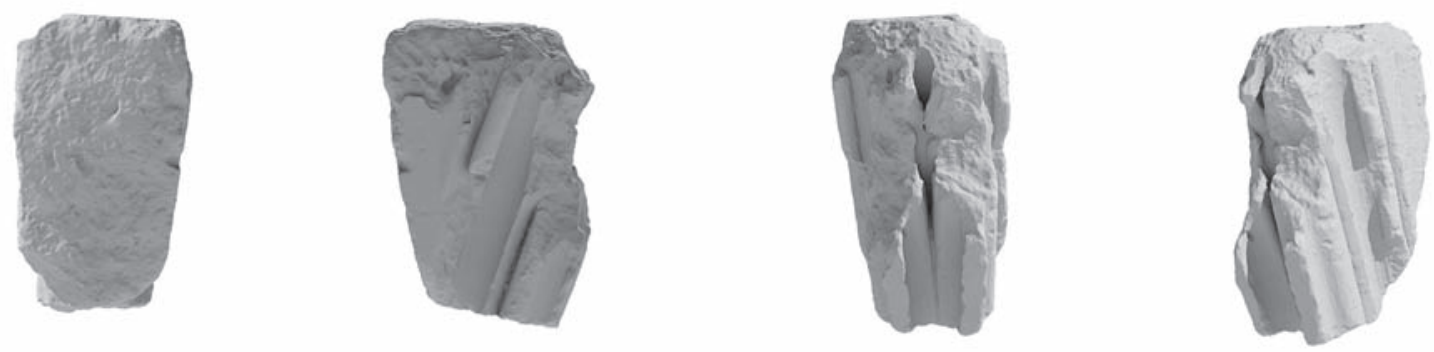

4. kép: A fecskefarkas áthatású boltváll térszkennelt modelljének ortogonális nézetei

tás profilja megegyezik a vizsgált kőanyagéval. A boltozatból induló csonk jelenlegi formájában fecskefarkas áthatásra utal, de minden része törésfelület, így a vízszintes síkokat leszámítva a kőelem térbeli helyzetét nem sikerült megállapítani. A rejtettebb helyeken, mélyedésben, kevésbé sérülten megmaradt áthatások rendkívül hasonlítanak a siklósi várkápolnában látható boltvállakhoz.

\section{A boltozat rekonstrukció alapjai}

A boltozati csomópontok tetején mérhető szögek alapján rekonstruálható az az elméleti háló, amelyen a boltozat alaprajzi vetületét szerkesztették. A kőfaragómunka megkezdésekor ezeket a vonalakat más szerkesztővonalakkal együtt bekarcolták a kifaragandó kőtömbbe. A munka során ezek sokszor megmaradtak, így közvetlen mérésre is lehetőséget adnak. Több csomóponton Székesfehérváron is lehetőségünk volt ilyen mérést végezni. A kézzel és szekennelt állományokon CAD programban végzett mérések alapján a boltozatot közel szabályos 60 fokos hálón szerkesztették. Az egyik vonal a boltozat gerincére merőleges, a másik két szerkesztővonal ezzel 57-58 fokos szöget zár be. A két ferde állású vonal egymással 64-66 fokos szöget zár be. Az értékek viszonylag következetesek, ugyanúgy tulajdoníthatóak a kőfaragói munkamenetből származó jellegzetességnek, mint a boltozat nagyon enyhe torzításának. ${ }^{19}$

A boltozat térbeli kiemelésére a bordacsomópontokon mérhető emelkedési szögekből következtethetünk. A csomópontok tetején úgynevezett illesztő fület hagytak a kőfaragók, ehhez a boltsüvegek falazatába bekötött tagozathoz viszonyítva állapították meg a vízszintes síkokat az építés során. A székesfehérvári kőanyagban szinte miden csomóponton megmaradt ez a tagozat. Az illesztő füleknél mért szögek az első faragványcsoportban 11-12 fokos szöget mutatnak, a második típusba tartozó $X$ alakú csomópontoknál 23-24 fokot, a harmadik szarkaláb alakú csomópontnál pedig 35-36 fok mérhető. Ez a sorozat egy 0-1-2-3-4-5 részre tagolt szerkesztési ívből származtatható. A szerkesztésmenet szerint az azonos hosszúságú 0-1-2-3-4-5 szakaszok együttes hossza adja a görbületi sugarat, amely az egész boltozat minden elemére érvényes. Az 1,2,3,4 pontokban felvett függőleges és körív metszete adja meg a csomópontok helyzetét. A 0 pontban felvett egyenes a záradék helyét jelöli ki. Az 1 pontban felvett függőleges vonal és körív metszéspontja összekötve a kör középpontjával a függőlegeshez viszonyítva megadja a bordacsomópont emelkedési szögét. Ugyanúgy, mint a csomópontok tetején mérhető szög a vízszinteshez viszonyítva. A csomópontok térbeli helyzete a záradékhoz képest, ugyanígy minden csomópontban számolható.

A 0-5 tagolás és feltételezett boltszakasz mérete alapján a következő háló szerkeszthető. A boltszakasz szélessége a régészeti adatok alapján 13,90/14,20 méter nagyságú, az utólagos belső támpillérek belső síkjához viszonyítva. A fennmaradt pillérek tengelytávolsága átlagosan 5,65 méter. Erre a meghatározott sűrűségú háló 172-173 centiméteres szakaszokkal szerkeszthető. Ez az adat megfelel a késő gótikus hálóboltozatok átlagos csomópontok közötti alaprajzi vetületben mérhető bordahosszának. Ez általában 150 és 210 centiméter közötti érték. Hasonló méretű a szinte azonos szélességú Szeged-alsóvárosi ferences templom bordarácsa, amely 178 centiméteres szakaszokra tagolódik, és az egykori pécsi székesegyház kórusát fedő boltozatnak is ilyen méretű volt a szerkesztőhálója. Megjegyzendő, hogy a szerkesztőháló a meghatározott boltszakasz arány szerint 4-5 fokos torzítással illeszkedik a legtökéletesebben. ${ }^{20} \mathrm{~A}$ szerkesztőháló adatai és a bordacsomópontokon megfigyelhető irányok alapján felvázolható a boltozat bordarácsának egykori rendszere. Középen rombuszmezőkből álló csillagalakzat helyezkedett el. Ehhez oldalt két sorban boltozat gerincére merőleges állású oldalú rombuszmezők helyezkedtek el, ezekhez kapcsolódtak a boltvállakba futó bordák. A boltfiókokhoz csatlakozó rész kialakítása, a rozsnyói székesegyház hajójában ma is fennálló boltozatéval lehetett megegyező. A meglévő csomópontok, pontosabban az erről a részről hiányzó elem alapján két változata is lehetséges en-

19 Szőke 2009. 453-455.

20 Ez az adat a csomópontok szögeinek tudatos szükítésére utal 
nek a részletnek. Fennmaradt azonban egy bizonyosan ehhez a boltozathoz tartozó fecskefarkas átmetsződésű töredék. Ilyen vállmegoldást csak a rozsnyói változat esetében lehetett kialakítani. Boltszakaszok szélein a boltozat gerincére merőleges bordák megszakítás nélkül átfuthattak a boltvállak között. Ez a megoldás a szerkesztőháló rendszerébe nem illeszkedik közvetlenül, a záradéki, a boltozat gerincével párhuzamos rombuszmezőket, két háromszögű elemre tagolják ezek a bordák. A háromszögű mezőket határoló egyik bordának ebben az esetben a záradékból kiemelt, olyan ívszegmensnek kell lennie, amelynek végpontjai azonos magasságon vannak. ${ }^{21}$ Ennek a megoldásnak a használatát a záradék közeli csomópontok következetesen ehhez a megoldáshoz illeszkedően faragott tagozatáthatásaiban figyelhetjük meg.

\section{A székesfehérvári prépostság boltozatának művészettörténeti kapcsolatrendszere}

A 15. század első felében már Magyarországon elterjedtek voltak azok az egyszerü hálóboltozat típusok, amelyek Peter Parler és körének munkáiban korábban megjelentek Prágában. Ezek a páros bordás keresztháló és a sorolt rombuszháló boltozatok. ${ }^{22}$ Ennél bonyolultabb rajzolatú boltozatok közül a 15. század 30-as 40-es éveiben Landshutban megjelenő hatágú csillagmotívumra szerkesztett hálóboltozatok is épülhettek a 15. század második felében, ilyen szerkezetekre azonban biztosnak tekinthető datálással csak az 1490-es évektől rendelkezünk. Az 1480-as években már az előző boltozattípus továbbfejlesztett változatának is tekinthető Wechselberger-motívum szerint szerkesztett boltozatok építésére is van példa. Ezek az emlékek a korszak egyik vezető késő gótikus mühelyéhez, a landshuti Szent Márton dóm páholyához köthetőek, valamint a Landshut és Salzburg környéki építőgyakorlatból eredeztethetőek. ${ }^{23}$ A 16. század elejétől egy az előzőtől markánsan különböző, új boltozatépítési stílus jelenik meg Magyarországon, amely nem csak a megelőző építési gyakorlattól különbözik, hanem részben az előképként kimutatható németországi példáktól is. A ma is álló vagy bizonyosan ismert épületek, például a nyírbátori református templom, Szeged-alsóvárosi ferences templom, a bakabányai plébániatemplom, az egykori pécsi székesegyház és egykori domonkos templom, és számos szászföldi és székelyföldi templom boltozatai és térszervezése olyan jellegzetességeket mutatnak, amelyek a mintaadó régiókban sem jelennek meg teljességükben. A magyarországi építkezések első példája és az új építési gyakorlat kialakítója a székesfehérvári építkezéseken dolgozó műhely lehetett. Ismert, hogy Hunyadi Mátyás fehérvári építkezéseire jelentős anyagi forrásokat felhasználva, a kor legjobb mesterei közül alkalmazott sokakat. ${ }^{24}$ A magyarországi késő gótika, és elsősorban a boltozatépítés sajátosságai a württembergi építési gyakorlat felé mutatnak rokon vonásokat, azonban a már említett landshuti és emellett az augsburgi jellegzetességek is kimutathatóak. E három, egymással szomszédos, de saját jellegzetességeket is mutató iskola hatása együtt érzékelhető a magyarországi építkezéseken a 16. század elején. A leggyakoribb szerkezetek a sorolt rombuszháló boltozatból továbbfejlesztett rajzolatú boltozatok, amelyek már a 15. század második felétől kimutathatóak a württembergi építkezéseken. Egységes alaprajzi vetület szerint szerkesztett sorozatba illeszkednek a következő boltozattípusok.

A középen található rombuszmezőkből kialakított csillagmotívum mellé rendelt rombuszmezőkből kialakított legegyszerủbb mustrára példa a gyulafehérvári Lázói-kápolna boltozata (1516). ${ }^{25}$ Erre a típusra számtalan példa adott, Magyarországról a lőcsei plébániatemplom északi előcsarnokában épült ismert, és felmérésből 
tudjuk, hogy az egykori dévai református templom szentélyében is ilyen boltozat állt. ${ }^{26}$ Ennek a változatnak több példája látható a württembergi kolostorok kerengőiben is. A következő változat arányai megegyeznek, a sorolt rombuszháló alapváltozatának arányaival, és részben a bordarácsuk is megegyező. Ezek közös vonása a centrális kompozíció és a szakaszolhatóság. Az alaprajzi vetület szerint felépítésük olyan, mintha az alapváltozat rombuszmezőit osztották volna a felező pontokban további rombuszmezőkre, amelyek közül a boltvállhoz kapcsolódókat egy, a szögfelezőben futó bordával helyettesítették. A közbeeső bordák pedig Y alakban találkoznak. Ennek a boltozatnak a térbeli felépítése az alapváltozathoz hasonlóan lehet erősen szakaszolt is, de egységes vezetésű, nem hullámzó gerinccel is szerkeszthetőek. Ilyen boltozat a rozsnyói székesegyház fóhajóboltozata, valamint a simontornyai várkápolna rekonstruálható boltozata. A szakaszolt kiemelésre pedig a rottweili Heilig-Kreuz Münster jó példa. Ez a boltozattípus rendkívül elterjedt forma, a Stuttgart környéki építkezéseken már a 15. század második felében gyakorta használták. Ezek közül a münsingeni plébániatemplom szentélyboltozata biztosan köthető Hänslin Jörghöz, annak az Aberlin Jörgnek a testvéréhez, akinek a Swäbisch Gmünd-i Heiligen Kreuz Münster szentélyboltozatát is tulajdonítják. ${ }^{27}$

A székesfehérvári rekonstruálható főhajóboltozat ennek a típusnak egy olyan változata, amelynél a boltozat szakaszonként és oldalanként egy-egy rombuszmező sorral szélesebb. (A boltszakaszok különlegesen nyújtott arányára vonatkozó adatokat fentebb részleteztem.) Ilyen típusú boltozatra közvetlen analógia nincs, de minden egyes részlete kimutatható más hálóboltozatokban. A záradék alatt a középső, rombuszokból álló, csillaghoz kapcsolódó mezőknél egy olyan bordacsomópont található, amelynél a boltváll felöl érkező boltváll szöge 60 fokos, a záradékba emelkedő boltváll szöge pedig 120 fok, közülük az egyik emelkedési szöge kisebb. A bordák közül egy emelkedő és egy továbbfutó egy egyenesbe esik. Ez a kőtöredékek között legnagyobb számban fennmaradt bordacsomópont, amely közvetlenül a záradék alatt helyezkedett el. Ilyen típusú bordacsomópont minden említett boltozattípusban, - tehát a Lázói-kápolna mustrája szerint épültben és a rozsnyói típus szerint épületben is -, megtalálható, boltszakaszonként négy ilyen elem szükséges, és ezek közül kettő tükörszimmetrikus párja a másik kettőnek. A következő bordacsomópont a záradékhoz képest még egy szinttel lejjebb elhelyezkedő $X$ alakú kereszteződés, amely típus egyik említett példában sem található. Ez bizonyítja azt, - amit a bordacsomópontok emelkedési szögéből is tudunk - hogy a boltozat mustráját egy-egy sor rombuszmezővel bővítették oldalanként a rozsnyói típushoz képest. Ennek következtében alakul ki az alaprajzi vetületben X alakú csomóponti kereszteződés. Ilyen típusú bordacsomópontok, más a sorolt rombuszháló elvén szerkesztett boltozatban is előfordulnak, ezeknél az alapvető mustra ugyanilyen jellegú bővítése figyelhető meg. llyen a trieri Antoniuskirche boltozata és a leibertingeni Wildenstein vár kápolnaboltozata - ez utóbbi záradéki részének szerkezeti felépítése teljes egészében megegyezik a Székesfehérváron rekonstruálhatóéval. ${ }^{28} \mathrm{~A}$ harmadik, szarkaláb alakú boltozati bordacsomópont szintén számos sorolt rombuszháló elvén szerkesztett boltozatban előfordul, és teljes egészében illeszkedik a másik két csomópont által meghatározott bordahálóba. Az eddig rekonstruálható szerkezetnél a boltfiókok kialakításánál nincs közvetlen adatunk, ellenben a boltvállak kőtöredékkel is bizonyítható fecskefarkas átmetsződése alapján, a Rozsnyón és Rottweilben is látható boltváll megoldással épülhetett a szerkezet. A záradékhoz közeli csomópont felmérése szerint az egyik továbbfutó boltindításnak a másikénál laposabb szögú indítása miatt a boltozat erősen szakaszolt térbeli felépítést mutatott, mint Rottweilben. Ugyanez a megoldás a pécsi székesegyház szentélyboltozatánál és a pécsi domonkos kolostor boltozatánál is megvolt, hasonlóan az augsburgi boltozatokhoz. ${ }^{29} \mathrm{~A}$ homogén felépítésű egységes rombuszmezőrács és a rövid boltszakaszok részben a württembergi példákkal mutatnak rokon vonásokat, a konstrukció szakaszoltsága és a fecskefarkas boltváll kialakítás viszont az augsburgi megoldásokra jellemző.

A Székesfehérvár nyomán épült magyarországi boltozatok közül a Szeged-alsóvárosi, a somogyvári, a bakabányai és a pécsi székesegyház hosszházában épült boltozatok közvetlen rokonságot mutatnak az Aberlin Jörg által épített, 1490 körül befejezett Swäbisch Gmünd-i szentélyboltozattal. A nyírbátori református templom, a selmecbányai Szent Katalin templom, a kolozsvári Farkas utcai templom hajójában feltételezhető boltozattípus, - amelynek fennálló másolatai a nagysinki, szászújfalui, nagybaromlakai, miklóstelki templomokban találhatóak - pedig a homogén rombuszmezőkből felépülő egységes rácsozatú szakaszolatlan boltozatok példái. ${ }^{30}$ Ezeknek szintén württembergi analógiái vannak, mint például a heilbronni Kilianskirche szentélyboltozata. ${ }^{31}$ Az augsburgi hatásokra pedig rendkívül erős analógiát mutat a pécsi székesegyház szentélyboltozata és a pécsi egykori domonkos kolostor hajóboltozata. ${ }^{32}$ Így a Székesfehérvárhoz közvetlenül kapcsolódó építkezéseken kimutatható mindhárom olyan építészeti iskola, amelyet a székesfehérvári műhelynél feltételezhetünk. Szoros kapcsolat látható az analógiaként felhozott boltozatok építtetői és Mátyás környezete között is. Simontornyát

26 Sarkadi Nagy 2010. 935-967.

27 Hänslin Jörgre életrajzi adatok: http://www.kirchkunst.de/glossary_entries/view/327

28 http://commons.wikimedia.org/wiki/Category:Chapel_of_Burg_Wildenstein_(Leibertingen)?uselang=de; http://farm5.staticflickr. com/ 4112/4962985275_1fdde3d664_z.jpg

29 Szőke 2012. b.

30 Papp 2005. CLXXI 418. kép.

31 http://farm4.staticflickr.com/3065/2791378889_34c5eaacfb_z.jpg?zz=1

32 Kárpáti-Szekér 1994. 235-248. 

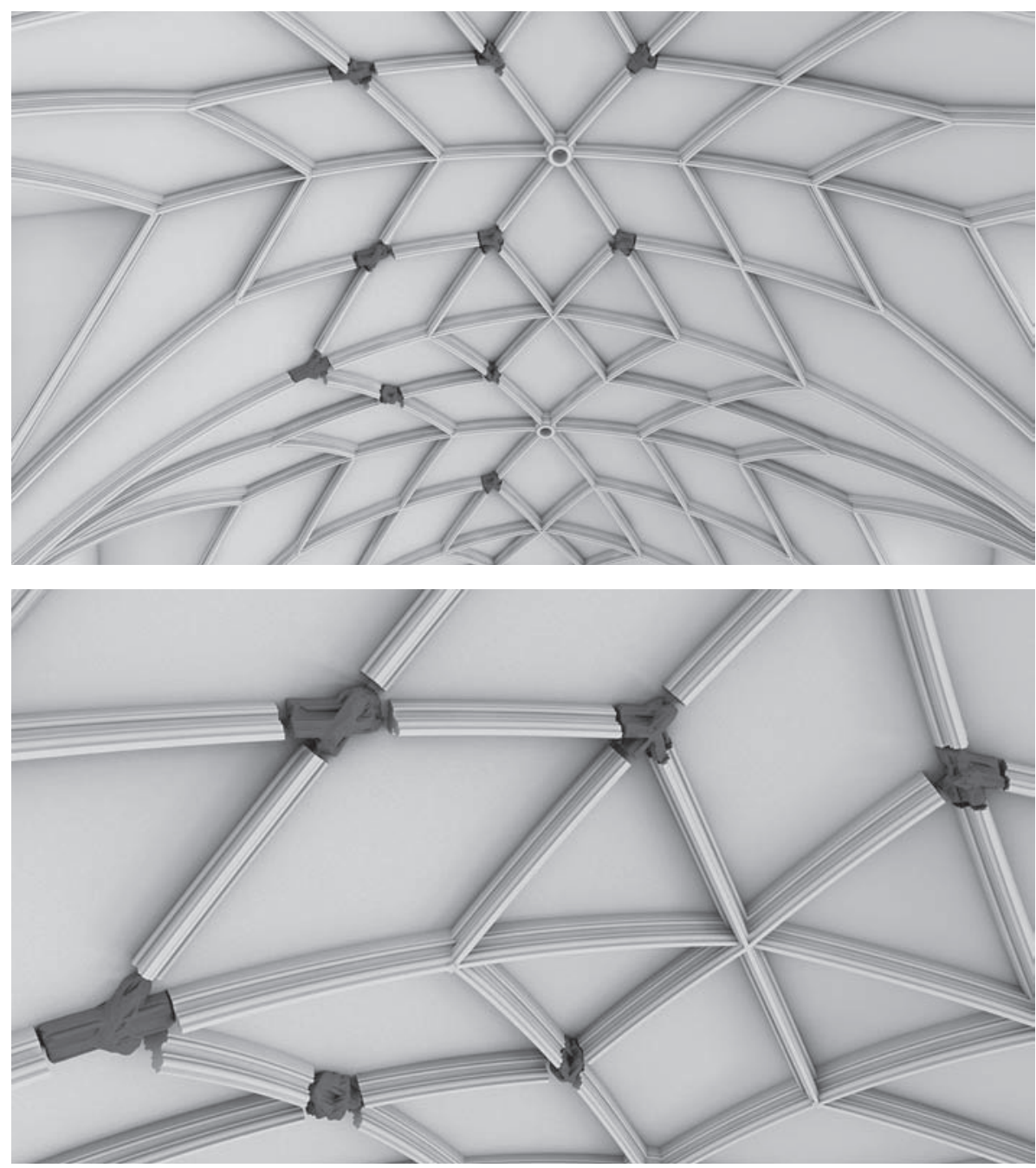

\section{6-7. kép: A rekonstruálható hálóboltozat záradékának nézete a bordacsomópontok térszkennelt modelljének} beillesztésével.

Mátyás udvaronca és diplomatája Buzlay Mózes építtette 1508 előtt. ${ }^{33} \mathrm{~A}$ rozsnyói székesegyházat, akkori plébániatemplomot Bakócz Tamás esztergomi érsek 1506 előtt. ${ }^{34}$ Hasonló boltozat kőanyaga található az esztergomi kőtár anyagában is, amely feltételezhetően a székesegyház szentélyéhez és kórusához tartozott. ${ }^{35} \mathrm{~A}$ pécsi építkezések pedig Mátyás kincstartójához, Ernuszt Zsigmondhoz köthetőek, a szentélyboltozat biztosan datálható 1505-re. A szegedi és a kolozsvári ferences templomokat pedig maga a király alapította, bár mindkettőt a Jagellók idején fejezték be, Szegedet 1503-ban, Kolozsvárt még később. Az említett építkezésekben közös, hogy mind 1490 után zajlottak, és 1500 és 1510 között fejeződtek be, tehát az udvarközeli építtetők a király halála után adtak munkát az egykori székesfehérvári múhely itt maradt vagy helyi tagjainak. Magyarázatul szolgálhat ez arra az adatra is, hogy a rendkívül szoros augsburgi igazodást mutató, a pécsi székesegyház szentélyboltozatát építő, neve alapján magyar, Demeter kőfaragó hol szerezhette meg tanultságát. A jól dokumentált augsburgi Burkhardt Engelberg életrajzában egyelőre nem mutatható ki Demeter nevú tanítvány vagy segéd, viszont a Fehérváron látható, augsburgi igazodású jegyek, mint a szakaszoltság és különösen a fecskefarkas áthatású boltvállak, bordaorr túlfutások arra utalnak, hogy a fehérvári kőfaragók között augsburgi tanultságú is volt. Maga a székesfehérvári boltozat az említetteknél régiesebb formát mutat, különlegessége azonban, hogy fecskefarkas kialakítású boltvállai egy Anjou-kori függőleges, profilozott faltagolási rendszerrel vannak áthatásban. Maga a bordaprofil is az érett gótika formavilágát utánozza, körtetagos profiljával - amelyet azonban bordatőben pálcák kísérnek -, egyértelműen jelezve késő gótikus eredetüket, ahogy ezt már Henszlmann Imre

33 Kubinyi 1993.

34 Gangel 1942

35 Szőke 2004. 
is megállapította. ${ }^{36} \mathrm{~A}$ székesfehérvári egykori prépostsági templom főhajóját behúzott támpillérek tagolják, amelyeknek megmaradt in situ lábazati részei a templom más Anjou-kori részeivel megegyező kialakításúak. Tóth Sándor véleménye szerint ezek tudatos archaizálás nyomát mutatják, és a Mátyás-kori boltozat elemei. ${ }^{37}$ A régészeti kutatások eredményei alapján, Biczó Piroska véleménye szerint ezek a belső támpillérek Anjou-koriak és a főhajóba tervezett hatsüveges keresztboltozatok alátámasztására szolgáltak volna. ${ }^{38}$

Ez a jelenség arra utal, hogy az Anjou-kori behúzott támpilléres faltagolási rendszerhez igazították a Mátyás-kori boltozatot, az Anjou-korihoz hasonló, de azzal nem teljesen megegyező bordaprofilt használva. ${ }^{39}$ Az Anjou-kori építmény hatsüveges boltozatához kialakított, erősen profilozott, függőleges faltagolási rendszer nélkül folytatódtak a Mátyás-kori boltvállak. A behúzott támpillérek alsó részének zárt, csak egyszerű élszedéssel képzett kialakítása ellentétben áll a felső rész gazdag profilozású megoldásával. Az alsó rész egyszerủ kialakítására a Fehérvárhoz bizonyíthatóan kötődő csatkai és tüskevári pálos templomok adnak támpontot. A két - alsó és felső rész közötti eltérésekre - fehérvári belső támpillérrendszerre, a franciaországi Albiban álló katedrálishoz hasonló, árkádokkal tagolt kétszintes megoldása adhat magyarázatot. Ennek bizonyítása azonban nem tartozik ennek a dolgozatnak a témakörébe. $A$ belső tér rajzi rekonstrukción történő bemutatásával azonban ennek a résznek a bemutatása elkerülhetetlen volt. A rajzi rekonstrukción viszont az a jelenség is bemutatható, hogy ha az árkádsor záradékának vonalában egy fiktív padlószintet feltételezünk ugyanolyan felépítésű és arányú behúzott támpilléres belsőt láthatunk, mint amilyen a Szeged-alsóvárosi ferences templom, vagy a kolozsvári Farkas utcai templom belső tere.

Az 1490-es évektől Magyarországon rendkívül elterjedt, különböző típusú hálóboltozatokkal fedett, de egységesen a boltozat és behúzott támpillér áthatásával felépített egyhajós terek prototípusát joggal kereshetjük a székesfehérvári építkezésen, tekintve hogy ennek a megoldásnak a magyarországiakhoz egészében hasonló közvetlen előzménye a mintaadó területeken nincs.

\section{A belső tér rajzi rekonstrukciójának alapjai}

A rekonstrukciós rajzok, a boltozaton kívüli, az épület belső terét ábrázoló részei a Szabó Zoltán által publikált adatok alapján készültek. ${ }^{40} \mathrm{~A}$ belső támpillérek mögötti korábbi falazati struktúrát is ez alapján ábrázoltuk. A belső támpillérrendszer formája Buzás Gergely álláspontját tükrözi, amely egyben e sorok szerzőjének álláspontja is. Ez a Szabó Zoltán által közölt, Anjou-kori és későbbi struktúrától részben eltérő formát mutat. $A$ korábbi román kori építkezések struktúráját illetően élénk szakmai vita folyik, a Szabó Zoltán által felvázolt empóriumos felépítés és az egyszerübb bazilikális térrendszer tekintetében, amelyet Biczó Piroska és Marosi Ernő is képvisel. ${ }^{41}$ Ebben a kérdésben az építészeti modellel csak annyiban kívánunk állást foglalni, hogy igyekszünk a jövőben az általunk bemutatott késő gótikus és Anjou-kori épületrészekhez kapcsolódó korábbi építményeket mindkét nézőpont szerint megjeleníteni. A képeken a templom olyan feltételezett Mátyás-kori formáját ábrázoltuk, amelyen a boltozat már elkészült, de az épülő csarnokszentély és a régi rész közötti román kori apszis még használatban van. A bizonytalan építészeti megoldású nyugati falat és a keleti apszist eltérő színezéssel fehéren hagytuk.

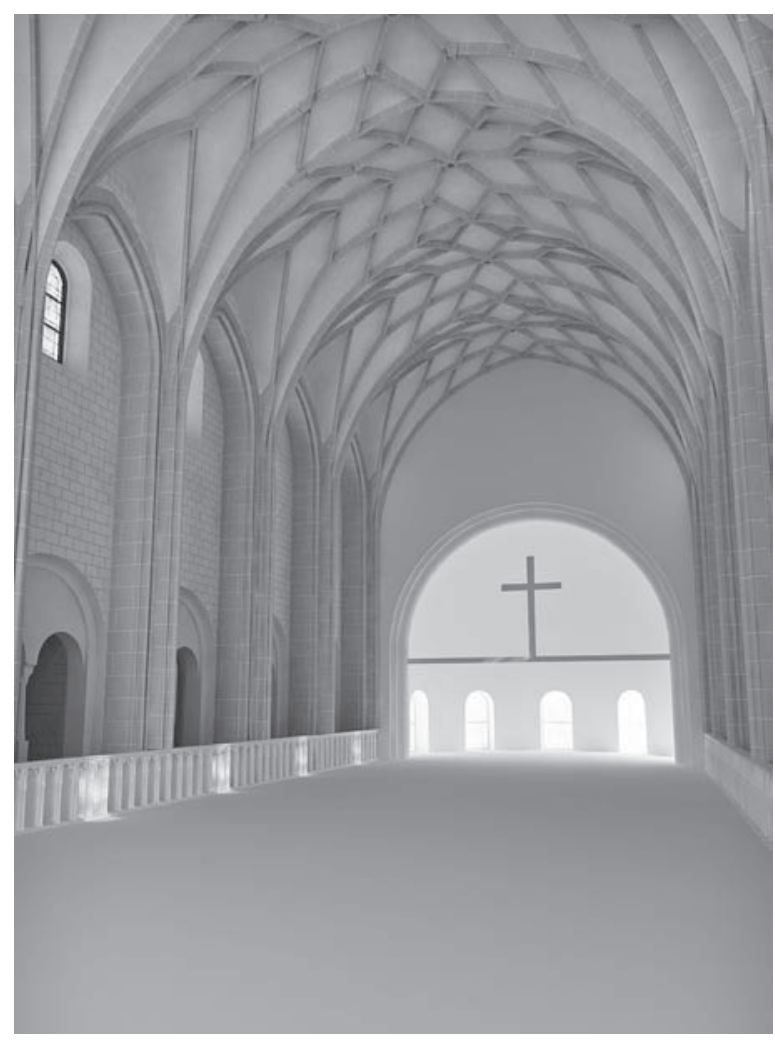

8. kép: A Székesfehérváron rekonstruálható belső tér az árkádok szintjén felvett fiktív padlósíkkal.

36 Henszlmann 1864. 157., 166.

37 Tóth 2010. 740. 41. lábjegyzet

38 Biczó 2011.

39 Az Anjou-kori profil körtetagos része nagyobb méretü, mint a Mátyás-kori bordáké, ez a Mátyás-kori boltvállon is mérhető

40 Szabó 2010. Szabó Zoltán könyvében metrikus, és metrikus rendszerre váltható korábbi mértékegységek szerinti adatokat és léptékkel ellátott tervrajzokat közöl, ezért a tervezési munka során ezeket vettük figyelembe. Az ettől eltérő térbeli felépítésre vonatkozó adatok még nem publikáltak.

41 Biczó 1996. 65-76. A Biczó Piroska által képviselt szakmai álláspont rajzi rekonstrukciója Branczeiz Zsuzsa munkájában található meg, Branczeiz 2012. 


\section{A térszkennelés lehetőségei a virtuális boltozatrekonstrukcióban és tervezésben}

A székesfehérvári boltozat számítógépes rekonstrukciója eredetileg vonalzókkal és szögmérővel végzett kézi méréseken alapult. A boltozati bordacsomópontok felméréséhez általában két személy együttműködése szükséges, megbízható adatok felvételéhez gyakran mind a négy kézre szükség van. A székesfehérvári csomópontokat Buzás Gergellyel mértük fel 2011ben. Ekkor a bordaprofilon kívül az emelkedési szögeket és bordák irányait rögzítettük. Az ebből készült számítógépes modell a most bemutatottal azonos. ${ }^{42}$ A térszkennelt kövek közvetlenül a modellbe helyezve igazolták a mérések pontosságát, és a rekonstrukció megalapozottságát. A térszkennelés elsődleges hozadéka a közvetlen bizonyítási lehetőség volt. A modell összevetése, és együttes bemutatása a fennmaradt kőtöredékekkel a hipotézisek alátámasztásában, valamint szélesebb közönség számára is átláthatóvá tételében rejt lehetőségeket. A terepmunka során a mérések menete többnyire dokumentáció nélkül zajlik, így



9. kép: Az 1. típusú boltozati bordacsomópont térszkennelt modelljének összehasonlító nézete a modellezett bordavázzal. ezek visszamenőlegesen csak helyszíni mérésekkel ellenőrizhetőek. A térszkennelt elemek nem csak azokban az adataikban dokumentáltak, amelyeket a mérés folyamán rögzítünk, hanem olyan másodlagos adatokat is megőriznek és hozzáférhetővé tesznek, mint a sérülések, festéknyomok festett és ragasztott leltári számok és egyéb olyan jellegzetességek, melyek felvétele a terepmunka során gyakran elmarad. A térszkennelt állományok azonos kőelemek esetén a kőfaragó munka pontosságának mérésére is lehetőséget nyújtanak. Ugyanígy a jellegzetes elemeiből részleteket megőrző, de önmagában nem mérhető kövek azonosítását is lehetővé teszi. A térszkennelt állományok mérésére közvetlenül CAD programokban van lehetőség, de az ezekről készített, forgatható pdf formátumú fájl használatával ezek ismerete nélkül is információhoz juthatunk.

A székesfehérvári Szűz Mária Prépostság egykori boltozatának kőanyaga a Szime3D program keretében került térszkennelésre. A felmérésben közreműködött:

Fehér András projektigazgató (SZIME 3D AR)

Balogh András projektigazgató (Pazirik Kft.)

Laki Boglárka tanácsadó (SZIME 3D AR)

Bödő Gábor e.h. (SZIME 3D AR)

Végh Mátyás 3D grafikus (Pazirik Kft.)

Appelshoffer Martin 3D grafikus (Pazirik Kft.)

\section{Összefoglalás}

A székesfehérvári Szűz Mária prépostág, a Magyar Királyság egykori koronázó temploma a középkorban számos átépítés során nyerte el végleges kiterjedését. Utolsó jelentős bővítését Hunyadi Mátyás uralma idején kezdték meg, ekkor nagyméretű csarnokszentély építésébe kezdtek. A nagymértékben elpusztult épület területéről, a román kori majd később érett gótikus stílusban átépített főhajó pusztulási rétegeiből késő gótikus boltozati elemek kerültek elő. Ezek ahhoz a hálóboltozathoz tartozhattak, amely a Mátyás kori építkezések nyitányaként a régi épületrészek befejezéseként épülhettek. A leletek Henszlmann Imre ásatásai alkalmával az 1860-as években kerültek napvilágra. Többet közülük Henszlmann Imre publikációjában is említett, valamint rajzaikat is közölte. A székesfehérvári kőtárban őrzött boltozati bordákat és csomópontokat térszkenneres eljárással rögzítettük. A szkennelt állományokból készült a boltozat 3D rekonstrukciója. A rekonstruált bordás hálóboltozat formailag illeszkedik a Mátyás és Jagelló-házi uralkodók idején épített hálóboltozatok körébe, bizonyítható datálása alapján, pedig ezeknek a boltozatoknak a mintaadó példája lehetett, hiszen építési ideje mindegyiket megelőzte. Ezzel a boltozattal jelenhettek meg a Peter Parler által szerkesztettnél összetettebb alaprajzi vetületű bordaráccsal épített hálóboltozatok Magyarországon. A boltozat mérete kiemelkedő, hiszen a több mint 17 méter széles főhajó felett emelkedett, amelyet a belsőben

42 A számítógépes modell ugyanazon adatok alapján azzal a különbséggel lett módosítva, hogy a térszkennelt elemek helyére eső bordákat külön elemként ki lehessen kapcsolni. 
felépített támpillérek 14 méteresre szűkítettek. A jelenleg a rommezőn is megtalálható belső támpillérek Anjou-kori építésűek, ezekhez szerkesztették a Mátyás-kori hajóboltozatot. Ennek az építési kötöttségnek a következtében jöhetett létre az a belső támpilléres szerkezeti megoldás, amelynek ma is álló példáit láthatjuk a Szeged-alsóvári ferences templomban, és számos késő gótikus stílusban átépített templomon a szászföldön. A stílus legmonumentálisabb példája a kolozsvári Farkas utcai templom hajója volt, ennek belső támpilléréi állnak eredeti formájukban, jelenlegi bordás csillagboltozata későbbi építésű.

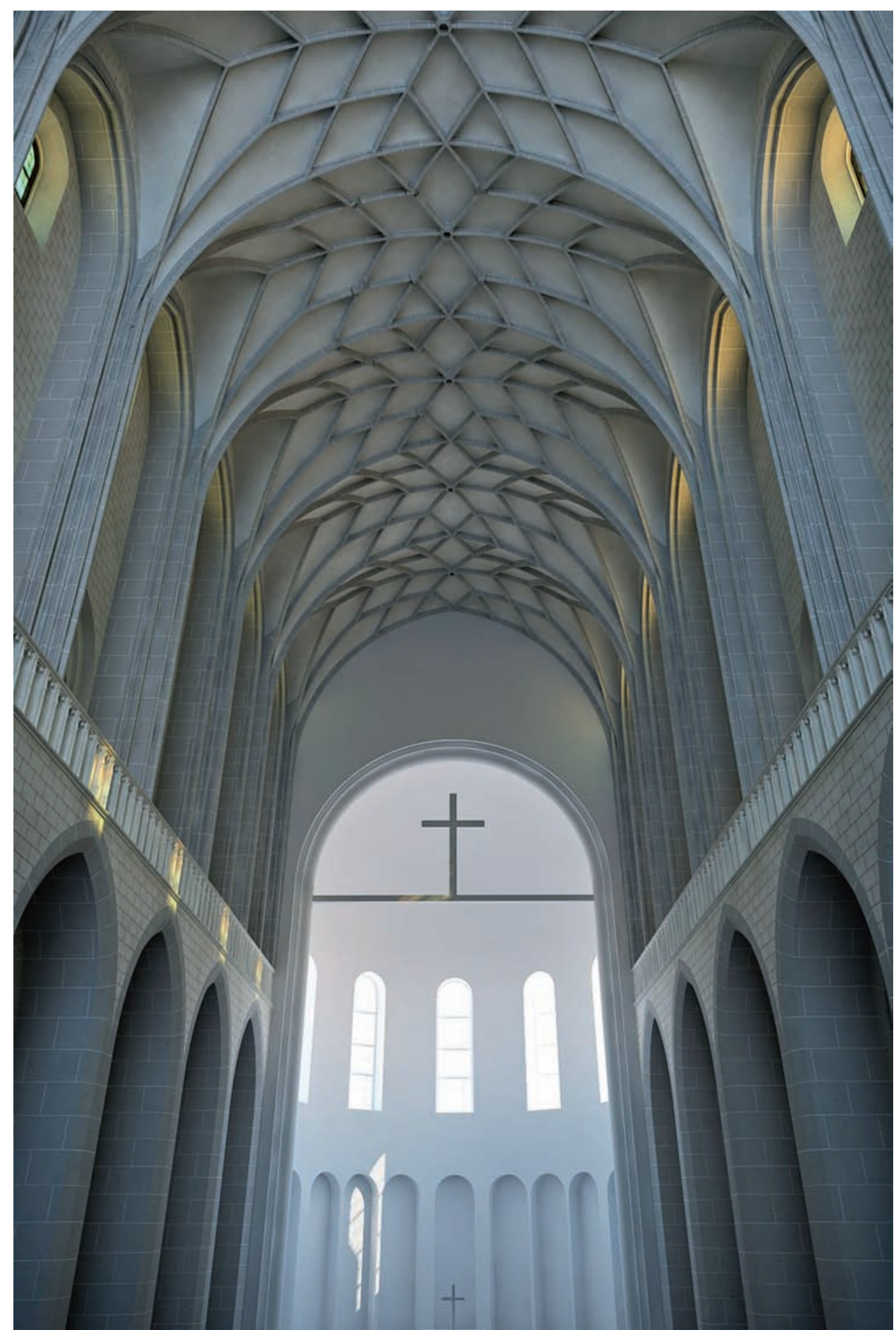

10. kép: A székesfehérvári Szüz Mária prépostság templomának föhajója kelet felé a rekonstruált hálóboltozattal 


\title{
Die ehemaligen Wölbungen der Propstei Jungfrau Maria von Székesfehérvár
}

\begin{abstract}
BALÁZS SZŐKE
Die Propstei Jungfrau Maria in Székesfehérvár, die ehemalige Krönungskirche des Königreichs Ungarn erreichte ihren endgültigen Umfang im Mittelalter nach zahlreichen Umbauten. Die letzte bedeutende Erweiterung wurde unter der Regierung von Mátyás Hunyadi begonnen, dann wurde mit dem groß bemessenen Bau eines Saal-Heiligtums begonnen. Aus dem Gebiet des im großen Teil zugrunde gegangenen Gebäudes, aus den Zerstörungshorizonten des romanischen und später im gotischen Stil umgebauten Hauptschiffes sind spätgotische Wölbungselemente vorgekommen. Die Funde wurden während der Ausgrabungen von Imre Henszlmann in den 1860er Jahren zum Vorschein gebracht. Mehrere von diesen Funden erwähnte Imre Henszlmann in seiner Publikation und er veröffentlichte auch seine Zeichnungen. Die im Lapidarium von Székesfehérvár bewahrten Wölbungsrippen wurden mit Raumscannertechnik aufgenommen, um die 3D Rekonstruktion der Wölbung zu erstellen. Die rekonstruierte Netzwölbung stimmt nach ihrer Form mit den unter der Herrschaft der Jagiellonen und von Mátyás Hunyadi gebauten Netzwölbungen überein, aber sie konnte für diese Netzwölbungen aufgrund des bewiesenen Datums als Beispiel dienen, denn sie wurde schon früher gebaut. Das Maß der Wölbung ist erhaben, sie erhöhte sich über dem mehr als $17 \mathrm{~m}$ breiten Hauptschiff, das die innen gebauten Strebepfeiler auf $14 \mathrm{~m}$ Breite verkleinerten. Die inneren Strebepfeiler, die auch zur Zeit auf dem Ruinenfeld zu finden sind, wurden in der Anjou-Zeit gebaut, zu diesen auch die Schiffwölbung später in der Mátyás-Zeit gebaut wurde. Zufolge dieser Baugebundenheit konnte die Struktur der inneren Strebepfeiler zustande gekommen, deren auch noch heute stehende Beispiele in der Franziskanerkirche in Szeged-Alsóvár und in vielen im gotischen Stil umgebauten Kirchen im Sachsenfeld zu sehen sind. Das monumentalste Beispiel des Stils war das Kirchenschiff in der Farkas Straße von Kolozsvár, die inneren Strebepfeiler dieser Kirche stehen noch in ihrer ursprünglichen Form, die derzeitigen gerippten Sternwölbung wurde später gebaut.
\end{abstract}




\section{Irodalom}

Biczó P. 1996.: A fehérvári Szűz Mária-prépostság temploma. In.: Altmann Júlia et al.: Medium Regni. Budapest, 65-76.

Biczó P. 1999.: Érdy János leletmentésének tudományos jelentősége In.: 150 éve történt... III. Béla és Antiochiai Anna sírjának fellelése. A Szent István Király Múzeum Közleményei B. sorozat 49., Szerk.: Cserményi Vajk, Székesfehérvár, 16-24.

Biczó P. 2004.: Az Anjou temetkezések kutatástörténete. In.: Magyar királyi és förendi síremlékek. Budapest, 32-35.

Biczó P. 2011.: Das königliche Marienstift zu Székesfehérvár im Lichte der neueren Grabungen. Acta Historiae Artium Academiae Scientarium Hungaricae 52. 5-29.

Branczeiz Zs. 2012.: A székesfehérvári királyi bazilika: a Szűz Mária-prépostság és temploma, középkori romkert. Székesfehérvár

Buzás G. 2004.: A Szűz Mária prépostság temploma a XIV. században. In.: Magyar királyi és főrendi síremlékek. Budapest, 29-31.

Érdy J. 1853.: III. Béla király és nejének Székes-fehérvárott talált síremlékei. In.: Kubinyi Ferenc - Vahot Imre: Magyarország és Erdély képekben I. 42-48.

Gangel J. 1942.: Rozsnyó műemlékei In.: A Budapesti Kir. Magyar Pázmány Péter Tudományegyetem Művészettörténeti és Keresztényrégészeti Intézetének dolgozatai 77. Budapest

Halmos B. 2007.: A gyulafehérvári Lázói-kápolna boltozatának kutatása és címereinek feltárása. In.: Architectura religiosă medievală din Transilvania IV. - Középkori egyházi építészet Erdélyben IV. - Medieval Ecclesiastic Architecture in Transylvania IV. Szerk.: Adrian A Rusu - Daniela Marcu-Istrate - Szőcs Péter Levente, Satu Mare, 171-214.

Henszlmann I. 1864.: A székes-fehérvári ásatások eredménye. Budapest

Henszlmann I. 1876.: Magyarország ó-keresztyén, román, és átmeneti stylű műemlékeinek rövid ismertetése. Budapest

Kárpáti G. - Szekér Gy. 1994.: A pécsi ferences és domonkos kolostorok kutatása. In.: Koldulórendi építészet a középkori Magyarországon. Szerk.: Haris Andrea, Budapest, 235-248.

Kubinyi A. 1993.: A Gergelylaki Buzlaiak a középkor végén. In.: Horler Miklós hetvenedik születésnapjára. Szerk.: Lővei Pál, Budapest, 269-283.

Marosi E. 1997.: A középkor művészete 1250-1500. Budapest

Mentényi K. 2006.: A székesfehérvári Szűz Mária prépostsági templom román kori faragványai (A faragványok története a 19. században). PhD disszertáció

Papp Sz. 2005.: A királyi udvar építkezései Magyarországon 1480-1515. Budapest

Sarkadi Nagy E. 2010.: Adatok az eltűnt dévai templom történetéhez. In.: Építészet a középkori Dél-Magyarországon Szerk.: Kollár Tibor, Budapest, 935-967.

Szabó Z. 2010.: A székesfehérvári királyi bazilika építéstörténete. Budapest

Szőke B. 2004.: Az esztergomi vár kőtárában található késő gótikus boltozati bordaanyag feldolgozása In.: Az Esztergomi Vármúzeum Kőtárának katalógusa. Szerk.: Buzás Gergely - Tolnai Gergely, Esztergom, 100-105. és 186-188.

Szőke B. 2009.: Hálóboltozat maradványai a Magyar Nemzeti Múzeum kőtárában. In.: Reneszánsz látványtár, Virtuális utazás a múltba. Szerk.: Buzás Gergely - Orosz Krisztina - Vasáros Zsolt, Budapest, 453-455.

Szőke B. 2012. a.: A Wechselberger-Harperger motívum Délkelet-Erdély késő gótikus építészetében. In:Tanulmányok a székelység középkori és fejedelemség kori történelméből. Szerk.: Sófalvi András - Visy Zsolt, Énlaka-Székelyudvarhely, 201-218.

Szőke B. 2012. b.: A pécsi domonkos kolostor rekonstrukciója. Altum Castrum Online 2012, http://archeologia.hu/content/ archeologia/76/szoke-b-a-pecsi-domonkos-kolostor.pdf

Tóth S. 2010.: Dombó és a templomépítés módjai a gótikus Magyarországon. In.: Építészet a középkori Dél-Magyarországon Szerk.: Kollár Tibor, Budapest, 717-742. 